\title{
"Mendengar" sebagai Pelayanan Pendampingan bagi Kaum Muda
}

\author{
Johannes Lie Han Ing'
}

\section{Latar Belakang}

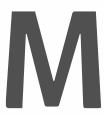
asalah kehidupan menghiasi kehidupan semua orang tanpa kecuali. Orang muda tidaklah imun terhadap permasalahan kehidupan. Bisa dikatakan orang muda sangat rentan dalam menghadapi masalah kehidupan karena secara usia mereka sedang menuju kepada kedewasaan. Secara psikis juga dalam kondisi yang labil. ${ }^{2}$

Kaum mudasendiri, di tengah masalah yang mereka hadapi sering kali justru merasakan bahwa mereka tidak memiliki orang lain yang mengerti mereka. Perbedaan generasi dengan orang tua serta rasa bahwa mereka sudah dewasa membuat mereka tidak ingin datang kepada orangtua mereka. Dunia yang semakin individualis cenderung membuat mereka merasa tersendiri. Ada banyak orang untuk tertawa bersama, tetapi untuk menangis bersama belum tentu ada yang bersedia.
Tidaklah mengherankan bila ada orang muda yang akhirnya dengan mudah terperangkap dalam informasi yang keliru yang mereka simpulkan sendiri dari berbagai sumber yang belum tentu dapat dipercaya validitasnya. Ada juga dari mereka yang tidak mendapat jalan keluar dan mengambil jalan pintas dengan melarikan diri dari kenyataan dan "meninabobokan" diri melalui entertainment dan terjerumus dalam alkohol dan NAPZA, bahkan perilaku seks bebas. ${ }^{3}$ Mark DeVries memberikan catatan bahwa "remaja adalah peringkat tertinggi dalam masalah bunuh diri, dan alkoholik". ${ }^{4}$ Sekalipun catatan tersebut ada di Amerika, namun dalam kenyataan di Indonesia tidaklah terlalu berbeda.

Panggilan pelayanan pendampingan bagi kaum muda menjadi sebuah keniscayaan. Diperlukan sebuah strategi yang tepat dalam pendampingan bagi kaum

1. Dosen STT Amanat Agung bidang Pastoral.

2. Erikson memberikan beberapa ciri masalah yang akan dihadapi bila perkembangan psiko-sosial mereka tidak sehat. Menurut Erikson, orang muda akan mengembangkan kemampuan untuk membangun keintiman au akan menjadi orang yang mengisolasi diri.

3. Data dari BNN tahun 2016 di Indonesia 1 dari 6 pelajar/mahasiswa minum minuman beralkohol, dan juga disimpulkan bahwa para generasi muda ki mulai terpapar dengan perilaku seks beresiko. http://www.bnn.go.id/_multimedia/document/20170227/ ringkasan_eksekutif_rev_ce k_18_feb.pdf (diakses 30 Mei 2017).

4. Mark DeVries, Family-Based Youth Ministry (Downers Grove, IL: IVP, 2004), 35. 


\section{Pemimpin Kaum Muda yang mendengar dan komunitas yang mendengar adalah sebuah pelayanan pendampingan yang diperlukan oleh orang muda. Dengan mendengar seorang pemimpin dapat memahami keberadaan yang sesungguhnya dari diri seseorang. Kisah hidupnya baru dapat dibaca dengan tepat.}

muda. Dean Borgman menuliskan "orang muda sering kali merindukan mentormentor yang memiliki jaminan moral, yang mau menerima dan menghargai mereka, dan yang dapat mengarahkan mereka kepada tujuan dan keberhargaan". ${ }^{5} \mathrm{Hal}$ ini menunjukkan sebuah kebutuhan anak muda dalam kebersamaan mereka dengan para pelayan kaum muda.

Strategi pendampingan yang memadukan pola pendampingan yang terintegrasi dengan peran serta komunitas menjadi satu strategi yang efektif dalam melakukan pendampingan bagi kaum muda. William T. Kirwan melihat bahwa Allah adalah memberikan Wahyu dan juga akal pikiran ${ }^{6}$ sehingga perlu memperhatikan bukan hanya Alkitab tetapi juga disiplin ilmuyang lain. Dalam pendekatan ini, kontribusi ilmu psikologi dan dasar secara teologis dipadukan.

Doug Fields mengingatkan bahwa "pelayanan kaum muda adalah tentang orang dewasa yang mengasihi para pelajar membangun relasi dengan mereka, mengarahkan mereka kepada Yesus". ${ }^{7}$ Relasi dalam kasih dari seorang pemimpin kaum muda dan tentunya bisa diperluas menjadi relasi dalam komunitas secara positif menjadi hal yang tidak dapat diabaikan. Komunitas, khususnya komunitas orang percaya tidak kalah penting dalam pendampingan kaum muda. Itu sebabnya strategi pendampingan perlu mengikutsertakan komunitas sebagai bagian dalam pendampingan pastoral.

Pendampingan yang sedemikian itu perlu dilakukan dengan benar. Bila klien (orang muda) tidak yakin dengan konselornya (pemimpin kaum muda), maka anak muda yang bermasalah tidak akan datang dan merasa memerlukan bantuan dari pemimpinnya. Selain perlu untuk membuat anak muda yakin dengan pemimpinnya, seorang pemimpin kaum muda perlu untuk mendapatkan sebanyak-banyaknya informasi dari orang muda yang mengalami masalah. Hal ini sangat diperlukan untuk membuat diagnosa yang tepat dari masalah seseorang.

5. Dean Borgman, Hear My Story: Understanding the Cries of Troubled Youth (Peabody, ME: Hendrickson, 2004 ), 5.

6. William T. Kirwan, Biblical Concepts for Christian Counseling: A Case for Integrating Psychology and Theology (Grand Rapids, MI: Baker, 2002), 30. Kirwan menyimpulkan ada beberapa model dalam konseling yang sering dipakai dalam melakukan pendampingan. 7. Doug Fields, Your First Two Years in Youth Ministry: A Personal and Practical Guide to Starting Right (Grand Rapids, MI: Zondervan, 2002), 84. 
Pemimpin Kaum Muda yang mendengar dan komunitas yang mendengar adalah sebuah pelayanan pendampingan yang diperlukan oleh orang muda. Dengan mendengar seorang pemimpin dapat memahami keberadaan yang sesungguhnya dari diri seseorang. Kisah hidupnya baru dapat dibaca dengan tepat. Di lain pihak, kebutuhan untuk didengar juga adalah kebutuhan yang besar dalam diri orang muda. Komunitas yang mendengar menjadi sebuah dukungan yang besar dan merupakan sebuah aspek sustaining yang penting dalam pendampingan pastoral.

Melalui mendengarkan kisah mereka pelayan kaum muda memahami diri orang muda. Ada kebutuhan yang mendesak dalam diri orang muda yang bisa dipenuhi ketika mereka didengarkan. Ada kekuatan yang besar dalam diri seseorang ketika ia merasakan bahwa ada komunitas yang menerima keberadaannya dengan keterbukaan komunitas untuk mendengarkan kisahnya.

\section{Aspek Penentu Respons terhadap Per- masalahan}

Aspek yang memengaruhi dalam membuat respons bisa dibagi menjadi aspek yang bersifat natur alamiah (nature), sesuatu yang ada di dalam kepribadian seseorang, dan aspek asupan (nurture), yaitu sesuatu yang berasal dari luar diri yang memengaruhi seseorang dalam memberikan respons terhadap permasalahan kehidupan. Aspek nurture juga dapat dibedakan menjadi hal yang dialami sebagai pengalaman pribadi dan hal yang menjadi masukan dari komunitas di sekitarnya. Aspek spiritual termasuk dalam bagian ini. Berikut secara singkat aspekaspek ini dijabarkan.

Pertama, aspek kepribadian. Aspek ini merupakan aspek natur alamiah seseorang. ${ }^{8}$ Contoh sederhana, seorang yang dikatakan memiliki ciri kepribadian yang sifatnya introver akan menanggapi masalah dengan senyap dan masalah cenderung dipendam dalam diri. Sementara seorang ekstrover akan mengekspresikan tanggapannya secara nyata. Aspek kepribadian hanya dipahami dan dikembangkan secara positif kekuatannya serta mengontrol semaksimal mungkin untuk mengeliminir kelemahannya. ${ }^{9}$ Mengenali keunikan dan keterbatasan dari aspek ini sangat penting.

Aspek kedua adalah aspek pengalaman hidup. Setiap orang merespons masalah berdasar pengalaman masa lalunya. Pengalaman masa lalu yang negatif menjadi sebuah trauma dan luka yang membuat seseorang menjadi lemah dan mudah hancur. Sebaliknya, ada pengalaman yang justru menempa dan menjadikan diri makin kuat dan tidak gampang

8. Pada mulanya tipe kepribadian yang dikenal adalah Sanguin, Kolerik, Melankolis, dan Plegmatis. Di abad 20, John Geier kemudian mengembangkan tipe kepribadian menjadi DiSC ${ }^{\text {m }}$ yang dipatenkan melalui perusahaannya Inscape, yaitu Dominan (Dominance), Memengaruhi (Influence), Tenang (Steadiness), dan Teliti (Conscientiousness). Katharine Cook Briggs dan anak perempuannya Isabel Briggs Myers mengembangkan teori tentang kepribadian yang didasarkan pada teori dari Carl Jung. Mereka mengklasifikasikan kepribadian melalui 4 elemen dengan variannya menjadi 16 macam kepribadian. Teori mereka dikenal sebagai teori MBTI $(M y e r s$ Briggs Type Indicator). Salah satu elemennya adalah introver/ekstrover.

9. Tim LaHaye, Temperamen yang Diubahkan (Surabaya: Yakin, 1971), 
hancur diterpa permasalahan. Dalam pendampingan pastoral, aspek pengalaman hidup dilihat sebagai bagian pembentuk diri seseorang. Howard Stone melihat bahwa ketika seorang bisa membingkai ulang pengalaman kehidupannya, maka hal itu akan dapat "menebus masa lalu dan menetralisir memori yang menyakitkan dan bahkan dapat melihatnya secara positif serta memberikan pencerahan".10 Pengalaman tersebut tidak bisa dihilangkan. Itu adalah sebuah realita dalam kehidupan di masa lalu yang sudah mewarnai dalam kehidupannya baik disadari ataupun tidak. Yang mungkin dilakukan adalah bagaimana melihat dan mendaur ulang pengalaman tersebut sehingga menjadi suatu pembelajaran dan pembentukan yang positif dalam kehidupannya.

Aspek ketiga adalah aspek spiritualitas. Spiritualitas perlu dibedakan dari religiusitas. Religiusitas lebih berbicara tentang praktik kehidupan beragama dengan segala ritualnya. Spiritualitas lebih berbicara kepada inti dari kehidupan seseorang dalam hubungannya dengan Allah. ${ }^{11}$ Aspek spiritualitas adalah aspek batin yang tidak terlihat, namun berpengaruh dalam menilai sebuah permasalahan dan pada gilirannya akan memengaruhi cara pandang dan cara menanggapi situasi kehidupan yang dialaminya. Aspek spiritualitas bersifat dinamis dan dapat dikem- bangkan. Spiritualitas seseorang yang dewasa akan memampukan dirinya untuk menghargai dan merayakan keberadaan diri serta memberi nilai terhadap pengalaman kehidupan. Kisah tentang Yusuf, adalah salah satu contohnya. Saat istri Potifar tertarik kepadanya, tanggapannya menunjukkan bahwa spiritualitasnya, yaitu kesadaran kehadiran Tuhan membuat ia menolak rayuan istri Potifar sekalipun konsekuensinya ia masuk penjara. ${ }^{12}$ Saat saudara-saudaranya ketakutan kalau ia membalas dendam, ia bisa mengatakan kepada saudara-saudaranya: "Memang kamu telah mereka-rekakan yang jahat terhadap aku, tetapi Allah telah mereka-rekakannya untuk kebaikan.....13 Hal ini membuktikan dengan jelas bahwa spiritualitas Yusuf yang dewasa membuat ia bisa menilai ulang pengalaman kehidupan yang "pahit" dan mengubahnya menjadi "manis". Bukan menjadi dendam dan luka tetapi kasih dan rasa syukur mewarnai hidupnya.

Aspek keempat adalah aspek komunitas. Kekuatan muncul di saat seseorang menyadari bahwa masih ada orang yang peduli kepadanya. Sebaliknya, dia akan lemah jika merasa bahwa dunia sepertinya tidak peduli. Lawrence Steinberg sebagaimana dikutip DeVries menyatakan bahwa "anak-anak dengan catatan akademis bagus [muncul] dari keluarga yang orang tuanya membangun hubungan de-

10. Howard W. Stone, Strategies for Brief Pastoral Counseling (Minneapolis, MN: Fortress Press, 2001 ), 9.

11. Evan B. Howard, The Brazos Introduction to Christian Spirituality (Grand Rapids, MI: Brazos, 2008 ), 16.

12. Baca kisah lengkapnya di Kejadian 39:1-20. Yusuf menolak dengan dasar kuat dari spiritualitasnya, yaitu ia tidak mau berbuat dosa (ayat 10)

13. Kejadian 50:20a. Saudara-saudara Yusuf kut kalau-kalau Yusuf akan membalas dendam. Kalau kemudian Yusuf tidak demikian, itu tentu tidak bisa dilepaskan dari kematangan spiritualitas yang dimilikinya.

\section{Youlflf | Mei 2016}


kat dengan sekolah". ${ }^{14}$ Komunitas bisa menghancurkan. Baru-baru ini ada permainan tantangan yang digemari oleh orang muda dan sudah memakan korban, yaitu skip challenge. Di Indonesia digemari oleh anak usia 9-16 tahun. ${ }^{15}$ Di pihak lain, komunitas yang secara positif membangun dipakai dalam teknik terapi kelompok yang mempertemukan orang-orang yang memiliki masalah yang serupa. Dalam kelompok mereka mendapatkan arahan dan dukungan untuk mengatasi masalah mereka. ${ }^{16}$ Semua itu menunjukkan pengaruh komunitas terhadap diri seseorang dalam menghadapi masalah kehidupan.

Alkitab dengan jelas menunjukkan pengaruh besar dari komunitas kepada seseorang. Misalnya, kisah kejatuhan karena komunitas seperti Amnon yang dinasehati Yonadab sahabatnya (2Sam. 13:1-15), Salomo yang terjatuh karena gundik-gundiknya (1Raj. 11:4), Rehabeam yang dinasehati teman-temannya (1Raj. 12:8). Secara positif ada juga perintah untuk tidak meninggalkan persekutuan yang saling menasihati (Ibr. 10:24).

Dari sini terlihat bahwa aspek spiritualitas yang dikembangkan akan memampukan seseorang melihat dengan sudut pandang yang tepat akan diri, situasi, bahkan mendaur ulang pengalaman hidupnya. Komunitas bisa menjadi sarana yang efektif dalam melakukan pendampingan.

\section{Kebutuhan Anak Muda untuk Didengar}

Ada satu kebutuhan yang hakiki bagi orang muda, yaitu kebutuhan untuk didengar dan kisah mereka diperhatikan. Ini adalah kebutuhan untuk mendapatkan dirinya berharga. Setiap orang memiliki "kisahnya" sendiri. Borgman menuliskan "Kita bukan hanya suka dengan cerita, ... kita adalah kisah yang dibentuk oleh sistem sosial yang penting: keluarga, komunitas, sekolah, media, teman sebaya, dan mungkin gereja. Kisah pembentukan kita termasuk sukacita dan kesedihan, keuntungan dan luka". ${ }^{17}$ Kisah dari seseorang yang didengarkan dan dipahami, akan membuat seseorang merasakan sebuah penguatan dalam kehidupan. Hal ini adalah salah satu aspek penting dalam pendampingan pastoral. Itu sebabnya ia menegaskan bahwa "melayani orang muda menuntut kita mendengarkan kisah mereka". 18

Anton Boisen mengetengahkan teori tentang "living human documents" yang menyatakan bahwa kehidupan seseorang

14. DeVries, Family-Based Youth Ministry, 63.

15. Permainan tantangan dengan menekan dada sehingga aliran oksigen sejenak terhambat dan membuat seseorang jatuh pingsan dan kejang sesaat. Baca lebih lanjut Dian Ismarani, "Berbagai \# Challenges Berbahaya dan Viral di Internet, Termasuk Fenomena Skip Challenge yang Menelan Banyak Korban," Youth Manual website, http://www.youthmanualcom/post/terkini/berita/ berbagai-challenges-berbahaya-dan-viral-di-internettermasuk-fenomena-skip-challenge-yang-menelan-banyak-korban (diakses 23 Mei 2017).

16. Ben Johnson, "Psychotherapy: Understanding Group Therapy," American Psychologycal Association (APA) website, http://www.apa.org/helpcenter/group-therapy.aspx (diakses 2 Juni 2017).

17. Borgman, Hear My Story, 11.

18. Borgman, Hear My Story, 29. Kesimpulan yang senada dinyatakan oleh Rich Van Pelt dan Jim Hancock dalam The Youth Worker's Guide to Helping Teenagers in Crisis yang mengatakan bahwa "tidak ada jalan pin untuk mendengarkan kisah [mereka] keseluruhan cerita" (hlm. 38). Baca Rich Van Pelt dan Jim Hancock, The Youth Worker's Guide to Helping Teenagers in Crisis (Grand Rapids, MI: Zondervan, 2005). 
dengan segala pengalaman hidupnya adalah seperti sebuah dokumen yang perlu dipelajari dan bahkan menjadi satu sistem pendekatan untuk memahami baik manusia maupun Allah. ${ }^{19}$ Interpretasi masalah dari sisi kebenaran mutlak dalam firman Tuhan memang tidak bisa dibantah, tetapi memahami "kisah" yang membuat seseorang sampai pada satu situasi permasalahan juga tidak bisa diabaikan.

Dalam kebutuhan untuk memiliki nilai diri dan di tengah situasi kehidupan yang tidak selalu bersahabat, maka kebutuhan anak muda untuk didengarkan kisahnya menjadi suatu hal yang perlu digarisbawahi saat melakukan pendampingan kepada mereka.

\section{Pelayanan "Mendengarkan"}

\section{Allah yang Mendengar sebagai sebuah Rujukan}

Mendengarkan adalah sebuah tindakan Ilahi yang dilakukan oleh Allah kepada umat-Nya. Dalam Perjanjian Lama, Allah memberi diri-Nya mendengarkan keluhan dan ratapan, bahkan sungut-sungut umatNya. Banyak kali disebutkan dalam Alkitab bahwa Allah mendengar seruan umat-Nya dan bertindak untuk menyelamatkan mereka.

Mazmur 62:9 mengatakan "curahkanlah isi hatimu di hadapan-Nya...". Bentuk kata perintah menunjukkan pentingnya untuk dilakukan. Kata "curahkanlah" memiliki makna seperti air yang dicurahkan keluar atau ditumpahkan. ${ }^{20}$ Dalam ayat tersebut, kata itu dipakai untuk mengungkapkan pencurahan apa yang ada dalam hati tanpa ada yang perlu untuk ditinggalkan/disimpan. Sebuah gambaran yang sangat jelas bagaimana seseorang dapat dengan leluasa membicarakan dan menceritakan segala keberadaan dirinya di hadapan Allah yang "mendengarkan".

Allah yang mendengar bukanlah Allah yang "perlu" untuk mendengar supaya tahu masalah manusia, ${ }^{21}$ tetapi karena Ia peduli dan mengerti kebutuhan manusia untuk didengar. Allah yang mendengar bukanlah untuk menghakimi sekalipun Ia adalah Hakim yang berkuasa dan maha adil. Ia mendengar karena dalam kasihNya Ia memberi ruang kepada manusia yang sudah berdosa untuk dilayani-Nya. ${ }^{22}$ Allah yang mendengar bukanlah Allah yang kemudian mengabulkan dan menuruti apa yang diinginkan oleh manusia, tetapi Ia mendengar dan mengarahkan dalam hikmat-Nya kepada apa yang benar dan yang menjadi jalan keluar.

\section{Pelayan yang "Mendengar"}

Mendengar adalah sebuah aktivitas yangsecaranyata memberikan tanda bahwa keberadaan seorang diakui oleh yang

19. Glenn H. Asquith Jr., "Anton T. Boisen and the Study of "Living Human Document's,"' Journal of Presbyterian History 60 (19621985): 244-265.

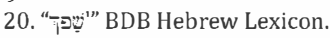

21. Allah adalah Allah yang mahatahu sehingga tidak perlu untuk mengumpulkan informasi supaya hu. Mendengar keluhan manusia bukanlah sebuah keperluan untuk diri-Nya, melainkan karena la mau memberi ruang bagi manusia.

22. Kisah Yunus adalah sebuah contoh yang menunjukkan bagaimana Allah mau mendengar baik orang Niniwe yang bertobat, maupun Yunus yang marah dan bahkan membimbing Yunus untuk mengetahui apa yang berkenan kepada Allah.

\section{YOulf}


mendengar. Ruang bagi orang yang sedang dalam keadaan bermasalah adalah sangat penting.

Seorang yang mendengar adalah seorangyang hadir bagi sesamanya. Gabriel Marcel sebagaimana dikutip Neil Pembroke mengatakan bahwa kehadiran bagi orang lain adalah untuk "menemukan kedalaman [kebersamaan] bersama-sama". ${ }^{23}$ Seorang yang mendengarkan harus hadir secara utuh, termasuk hatinya. Rich Van Pelt mengatakan bahwa "tugas Anda adalah mendengarkan seluruh person dari murid dengan keseluruhan person diri Anda seutuhnya". ${ }^{24} \mathrm{Hal}$ ini membutuhkan ketekunan untuk terfokus hanya kepada orang yang tengah didengarkan kisahnya tanpa terdistorsi dan terdistraksi oleh situasi dan pemikiran subjektivitas diri sendiri. Diperlukan satu keterbukaan untuk menerima keberadaan orang yang hendak didengar kisahnya. Pembroke menuliskan "ketika saya membuka diri saya kepada panggilan orang la in untuk bersama dengannya di tengah kepedihannya dan kebingungannya, saya bisa secara spontan merasakan bersama dia". ${ }^{25} \mathrm{Ke}-$ terbukaan dalam mendengar membawa pelayan kepada sebuah empati yang menjadi jalan masuk untuk relasi yang lebih intens guna pelayanan pendampingan yang efektif.

Dalam pendampingan, esensi atau peran pastoral yang selama ini dikembang- kan berdasarkan pemikiran Clebsch dan Jaekle, yaitu menyembuhkan, menopang/menyokong, membimbing dan mendamaikan (healing, sustaining, guiding, and reconciling). ${ }^{26}$ Peran-peran tersebut tidak pernah bisa dikerjakan tanpa mendengar kisah mereka yang dibimbing terlebih dahulu. Ketika seseorang didengar, ia merasa diterima. Hal itu adalah awal dari kesembuhan dalam diri mereka. Mendengar kisah mereka juga diperlukan untuk memahami keberadaan mereka yang sebenarnya sehingga dapat memberikan bimbingan yang tepat. Saat mereka didengar, mereka merasakan penopangan yang meneguhkan dan memotivasi mereka untuk bangkit dan menghadapi permasalahan. Kesemuanya itu akan membawa mereka kepada kemampuan untuk berdamai dengan diri, dengan situasi dan orang-orang yang terkait dengan permasalahan mereka.

Pelayan yang mendengar perlu memiliki hati gembala sebagaimana Allah yang menjadi gembala bagi umat-Nya. Keterbukaan diri untuk menerima seseorang apa adanya, konsistensi dalam penerimaan, kesabaran dalam mendengar, kesediaan kehadiran saat diperlukan adalah sebagian dari teladan yang dapat dilihat dari kehadiran Allah sebagai Gembala yang mendengar umat-Nya.

Mendengar dan memahami kisah seseorang perlu dipandang dengan sebuah

23. Gabriel Marcel, The Mystery of Being, vol.1 (London: The Harvill Press, 1950), 192 dalam Neil Pembroke, The Art of Listening (Grand Rapids, MI: Eerdmans, 2002), 18.

24. Pelt dan Hancock, The Youth Worker's Guide to Helping Teenagers in Crisis, 62

25. Pembroke, The Art of Listening, 21.

26. William A. Clebsch dan Charles R. Jaekle, Pastoral Care in Historical Perspective (Lanham, MD: Rowman and Littlefield Publishers, 1994), 33-66. 
bingkai teologis yang tepat. Borgman menegaskan bahwa "Secara mutlak semua kisah kita diawali dan disempurnakan di dalam Allah". ${ }^{27}$ Bingkai teologis yang membungkus seluruh kisah dalam kasih, anugerah serta desain Allah yang utuh dan sempurna, akan membuat kisah hidup menjadi sebuah jalinan episode-episode kehidupan yang berharga bahkan membentuk sebuah gam bar yang indah. Dalam dinamika pertumbuhan ke arah Kristus yang sempurna, kisah kehidupan menjadi pernik-pernik pembentukan dalam kehendak dan pemeliharaan Allah. Saat kisah-kisah kehidupan yang penuh dengan warna tersebut dibingkai secara tepat, maka kisah kehidupan menjadi sebuah perjalanan petualangan yang seru dan menarik untuk dijalani. Sudut pandang manusia yang terbatas melihat rangkaian kisah yang terjalin dari sebuah hubungan sebab-akibat. Karena itu, tidak mengherankan bila hal itu bisa membuat ia menemukan dirinya terjebak dalam sebuah lingkaran labirin yang sepertinya tidak memiliki pengharapan. Bingkai teologis akan membawa manusia kepada gambaran yang lebih luas, yaitu dalam peran serta Allah yang memberikan sebuah pengharapan dan kepastian.

Dengan bingkai teologis inilah seorang pelayan yang mendengar mem bawa kisah orang muda kepada kedalaman spiritualitas yang meneguhkan dan membangkitkan seseorang untuk menghadapi dan mengatasi masalah dengan cara pandang yang positif. Inilah peran pelayan kaum muda dalam mendampingi dan membimbing orang muda menemukan kisah hidupnya dalam Tuhan sehingga terjadi kesembuhan dan rekonsiliasi dengan kehidupannya.

\section{Komunitas yang Mendengar}

Manusia sebagai makhluk sosial tidak bisa dilepaskan dari pengaruh komunitas yang dimilikinya. Alkitab dengan gamblang mengingatkan akan dampak negatif dan pengaruh positif dari pergaulan kepada seseorang. ${ }^{28}$ Karena itu, dalam pelayanan kaum muda, peran serta komunitas tidak bisa diabaikan dan bahkan dapat dengan efektif berdaya-guna untuk sebuah pelayanan pendampingan.

Dalam kehidupan ada sebuah kebutuhan terkait dengan komunitas, yaitu kebutuhan memiliki dan dimiliki serta kebutuhan menjadi seorang yang bermakna. Borgman menegaskan "dua keinginan atau penggerak dasar dari manusia adalah kesatuan dan keberhargaan. Kita butuh mengasihi dan dikasihi, diteguhkan sebagai seorang yang berharga". ${ }^{29}$ Kebutuhan inilah yang membuat komunitas me-

27. Borgman, Hear My Story, 11.

28. Alki bencant banyak kisah dan pernyan ten hal ini. Beberapa kisah telah disebutkan di bagian pembahasan sebelumnya. Selain itu ada beberapa ayat seperti (Mzm. 50:18; Ams. 13:20, 22:24, 27:17; 1Kor. 15:33) secara jelas mengatakan ten pengaruh sebuah pergaulan a pengaruh komuni terhadap seseorang.

29. Borgman, Hear My Story, 92.

\section{Youlfh | Mei 2016}




\section{Kerjasama antara pelayan yang mendengar [pemimpin kaum muda] dengan komunitas yang mendengar merupakan sebuah kesatuan yang efektif dalam melakukan pelayanan pendampingan.}

miliki makna yang cukup besar dalam kehidupan seseorang, khususnya orang muda.

Seorang pemimpin kaum muda perlu menyadari dan memakai komunitas untuk memaksimalkan efektivitas pelayanan pendampingan. Komunitas dapat memberikan sebuah ruang yang memampukan seseorang mendapati bahwa dirinya tidak sendirian dan diterima oleh lingkungannya. Hal ini akan menguatkan seseorang untuk menemukan kembali akan keberadaan dirinya di tengah pergumulan masalah yang dihadapi.

Komunitas yang mendengar menjadi sebuah pelayanan yang mulia karena melaluinya seseorang mendapatkan penopangan bahkan pembimbingan. Secara psikologis, semakin banyak orang yang dirasakan memberikan dukungan, semakin kuat pula orang itu untuk berusaha.

Komunitas yang mendengar merupakan sebuah pelayanan imamat. Komunitas orang percaya adalah komunitas yang saling mendoakan, saling menghibur dan saling menguatkan. Richard Osmer me- negaskan bahwa "mendengarkan yang bersifat imamat (priestly listening) adalah yang pertama dan terutama, suatu aktivitas dari keseluruhan komunitas Kristen, bukan hanya pemimpinnya". ${ }^{30}$ Osmer melihat bahwa mendengar merupakan wujud kehadiran yang memiliki makna spiritual. Komunitas secara keseluruhan tidak boleh menjadi pasif dan bersikap tidak peduli. Kehadiran Allah yang mengayomi dan memberikan ketenteraman menjadi nyata melalui keterbukaan komunitas untuk mendengar dan memahami kisah seorang muda yang tengah bergumul dengan masalahnya.

Pemimpin kaum muda perlu mendidik dan membentuk komunitas kaum muda menjadi komunitas yang bukan hanya memedulikan diri sendiri dan bersifat individual dengan egosentris. Hal ini merupakan tugas besar di tengah arus dunia yang makin individualis dan yang menjadikan diri sendiri sebagai pusat dari hidup.

Komunitas yang mendengar dapat diwujudkan melalui kelompok sel atau KTB, spiritual friendship, kelompok kategori fungsi, dan yang sejenisnya. Pada umumnya komunitas yang kecil akan lebih berdampak dibanding dengan komunitas yang umum. Namun komunitas yang kecil ini harus juga berinteraksi dengan komunitas yang lebih besar sehingga tidak menjadi kelompok yang terlepas dari kumpulan induknya. Di sinilah peran pemimpin kaum muda yang memotivasi, mengoordinasi dan mengarahkan menjadi penting.

30. Richard R. Osmer, Practical Theology: An Introduction (Grand Rapids, MI: Eerdmans, 2008), 35. 
Kerjasama antara pelayan yang mendengar (pemimpin kaum muda) dengan komunitas yang mendengar merupakan sebuah kesatuan yang efektif dalam melakukan pelayanan pendampingan. Baiksang pemimpin maupun komunitas, keduanya secara harmonis dengan caranya yang mungkin bisa berbeda, mengarahkan seseorang untuk berjumpa dengan Allah di tengah pergumulan masalahnya. Dalam perjumpaan itulah seseorang akan dimampukan untuk menilai ulang setiap pengalaman kehidupan, membingkai kembali gambaran hidup di dalam Allah yang bekerja untuk menjadikan seseorang sesuai dengan desain-Nya.

\section{Penutup}

Pelayanan "mendengar" adalah sebuah pelayanan yang penting dan perlu dilakukan dalam melakukan pendampingan kepada orang muda yang mengalami pergumulan kehidupan. Mendengar kisah di satu pihak merupakan sebuah cara untuk memahami seseorang secara utuh, di lain pihak menjadi satu cara untuk melakukan pendampingan yang menyembuhkan, menopang/menyokong, membimbing, dan mendamaikan.
Dengan "mendengar" Allah dihadirkan secara nyata oleh Pemimpin kaum muda dan komunitas orang percaya. Sebagaimana Allah mendengar umat-Nya yang berseru kepada-Nya, demikian juga pemimpin kaum muda dan komunitas mendengarkan kisah dari seseorang.

Mendengar bukan hanya menerima kisah seseorang dalam bingkai humanitas, tetapi perlu untuk membawa orang tersebut melihat kisah hidupnya dalam bingkai teologis yang membungkus seluruh kisah dalam kasih, anugerah serta desain Allah yang utuh dan sempurna. Di situlah pelayanan mendengar menjadi sebuah pelayanan yang Ilahi dan imamat (divine and priestly). Aspek Spiritualitas yang digarap menjadi dasar dan elemen penting untuk memahami kisah hidup dan menemukan jalan keluar serta kekuatan untuk menjalani kehidupan di tengah pergumulan.

Pelayan kaum muda menjadi tokoh utama dalam melakukan pelayanan ini dan yang memampukan komunitas kaum muda menjadi komunitas yang mendengar. Dalam kebersamaan pelayan kaum muda dengan komunitas "mendengar", maka efektivitas pelayanan pendampingan menjadi optimal.

\section{YOulf}




\section{Daftar Pustaka}

\section{Buku}

Borgman, Dean. Hear My Story: Understanding the Cries of Troubled Youth. Peabody, MA: Hendrickson, 2003.

Clebsch, William A. dan Charles R. Jaekle. Pastoral Care in Historical Perspective. Lanham, MD: Rowman and Littlefield Publishers, 1994.

DeVries, Mark. Family Based Youth Ministry. Downers Grove, IL: IVP, 2004.

Fields, Doug. Your First Two Years in Youth Ministry: A Personal and Practical Guide to Starting Right. Grand Rapids, MI: Zondervan, 2002.

Howard, Evan B. The Brazos Introduction to Christian Spirituality. Grand Rapids, MI: Brazos, 2008.

Kirwan, William T. Biblical Concept for Christian Counseling: A Case for Integrating Psychology and Theology. Grand Rapids, MI: Baker, 2002.

Osmer, Richard R. Practical Theology: An Introduction. Grand Rapids, MI: Eerdmans, 2008.

Pelt, Rich Van dan Jim Hancock. The Youth Worker's Guide to Helping Teenagers in Crisis. Grand Rapids, MI: Zondervan, 2005.

Pembroke, Neil. The Art of Listening:Dialogue, Shame and Pastoral Care. Grand Rapids, MI: Eerdmans, 2002.

Stone, Howard W. Strategies for Brief Pastoral Counseling. Minneapolis, MN: Fortress Press, 2001.

\section{Jurnal}

Asquith, Glenn H. "Anton T. Boisen and the Study of "Living Human Documents."” Journal of Presbyterian History 60 (1962-1985): 244-265. 


\section{Internet}

"Hasil Survei Penyalahgunaan dan Peredaran Narkoba pada Kelom pok Pelajar dan Mahasiswa di 18 Provinsi Tahun 2016." Badan Narkotika Nasional. 2017. http://www.bnn.go.id/_multimedia/document/20170227/ringkasan_eksekutif _rev_cetak_18_feb.pdf (diakses 30 Mei 2017).

Ismarani, Dian. "Berbagai \# Challenges Berbahaya dan Viral di Internet, Termasuk Fenomena Skip Challenge yang Menelan Banyak Korban.” Youth Manual. Maret 14, 2017. http://www.youthmanual.com/post/terkini/berita/berbagai-challengesberbahaya-dan-viral-di-internet-termasuk-fenomena-skip-challenge-yang-menelanbanyak-korban (diakses 23 Mei 2017).

Johnson, Ben. "Psychotherapy: Understanding Group Therapy." American Psychological Association (APA). n.d http://www.apa.org/helpcenter/group-therapy.aspx (diakses 2 Juni 2017). 